\title{
PECULIARITIES OF APPLICATION OF THE MODEL OF ADAPTATION OF THE ORGANIZATIONAL STRUCTURE OF PHARMACEUTICAL ENTERPRISES TO THE EXTERNAL ENVIRONMENT CHANGES
}

\author{
I.V.Bondareva \\ National University of Pharmacy \\ Key words: model of adaptation; organizational structure; structural subdivisions; factors of the \\ external environment; manufacturing pharmaceutical enterprises
}

Today, a high degree of uncertainty and instability of the external environment determines the growing importance of adaptation of modern organizations to the new realities. For effective functioning of manufacturing pharmaceutical enterprises it is necessary to use the method that allows to describe the processes of transformation of the internal environment in the mode of constant adaptation to changes in the external environment. The peculiarities of application of the model adaptation of the organizational structure of pharmaceutical enterprises to changes in the external environment on the basis of interaction of its subdivisions are presented. The efficiency and speed of the adaptation process of pharmaceutical enterprises are determined by systemic relationship of three matrices: harmonization, which determines the principles and dynamics of interactive planning and evaluation of the results of adaptive transformations; resources determining the rationality of their distribution between the structural subdivisions of the enterprise to implement transformations; structural interaction that determines the optimal interaction based on the in-house staff motivation and other social and psychological factors. The adaptation process has been analyzed for the case when for the change of two essential factors of the external environment the pharmaceutical enterprise reacts by changing its three structural subdivisions. The mechanism of collection and subsequent transfer of information concerning the external environment of the manufacturing pharmaceutical enterprise and its influence on the structural subdivisions is given. It is expedient to use this model for preserving and strengthening the competitiveness of pharmaceutical enterprises at the domestic pharmaceutical market.

Complications of the market space due to development of competition, information technologies, globalization of business, and a high degree of uncertainty and instability of the external environment determine the growing importance of adaptation of modern organizations to the new realities. For effective functioning of manufacturing pharmaceutical enterprises it is necessary to use the method that allows to describe the processes of transformation of the internal environment in the mode of constant adaptation to changes in the external environment.

In the works of the well-known foreign authors the problems of management of enterprise adaptation to changes of the external environment are considered [5-10]. In scientific professional journals of pharmacy there are articles on modeling the process of adaptation of pharmaceutical enterprises to the impact of the external environment [4]. There is almost no information in literature about the adaptation models of manufacturing pharmaceutical enterprises to changes of the external environment, including model of the organizational structure adaptation to changing external environment components.

The aim of the work is the peculiarities of using the adaptation model of the organizational structure to changes of the external environment on the example of a manufacturing pharmaceutical enterprise.

\section{Materials and Methods}

The methods of expert assessment, economic and mathematical modeling and graphical method were use in the study.

\section{Results and Discussion}

To ensure survival, resistant functioning and development of pharmaceutical enterprises in the conditions of changes occurring in the external environment it is necessary to use the model that allows to describe the processes of transformations of the internal environment in the mode of constant adaptation to changes in the external environment.

When studying adaptive features of a company the adaptation is meant the intention of pharmaceutical enterprises to continuously reducing deviation of its position from the requirements dictated by the external environment changes. In this case the inefficient result is both negative (lagging) and positive (advance) deviation of the results of work of the enterprise from a certain value determined by the state of the corresponding environmental factor. The process of adaptive transformations can be represented in the form of economic and mathematical model of the tracking system closed by feedback according to the results of transformations (Fig. 1) [1-4]. The structure of the adaptation model contains the matrix of harmonization (interactive planning), 


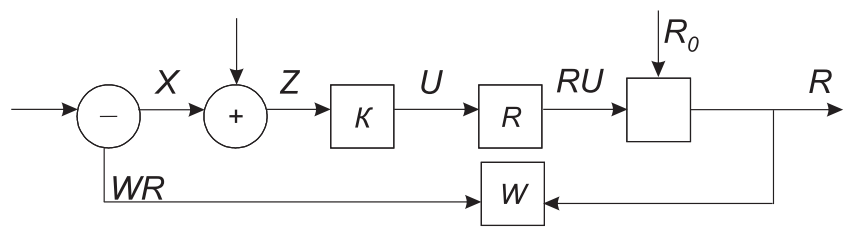

Fig. 1. The structural scheme of the model of adaptation of the organizational structure of pharmaceutical enterprises to changes in the external environment.

the matrix of resources and the matrix of structural interactions.

There are such components in this model:

- $\quad X-$ are the most significant environmental factors for pharmaceutical enterprises;

- $K-$ is the matrix of resources allocated to perform transformations for each factor of the enterprise internal environment;

- $R-$ is the matrix of the structural interaction (the number of variables of the enterprise internal environment subjected to adaptive transformations, namely the number of structural subdivisions of pharmaceutical enterprises);

- $\mathrm{W}-$ is the matrix of harmonization (this matrix specifies the structure of the the current state of the enterprise to the requirements of the external environment).

In this model, the complex of information and analytical measures allows management to assess the extent of compliance of the pharmaceutical enterprise state to the requirements dictated by changes in the external environment. It is described by a linear function of coordination $\Delta=\mathrm{X}-\mathrm{WR}$ where $\Delta-$ is the value of deviation of the enterprise state from the system of requirements specified by the state of the external environment and determined by some coordination function, which is dependent on measuring the variables of the external and internal environment.

The adaptation process was analyzed for the case when instead of two significant factors of the external environment the pharmaceutical enterprise responds by changing its three structural subdivisions.

Thus, the matrix of harmonization specifies the system of adaptation goals correlating the ratio and the necessary quantitative level of changes. In general, all factors of the internal environment (for example, all structural units or functional blocks) of the enterprise are to be agreed with each factor of the external environment. In the absence, in the opinion of management, of the need to harmonize any internal factor with this factor of the external environment the relevant component of the harmonization matrix is assumed to be zero. The matrix of harmonization shows which variables of the internal environment of the organization (and in what quantitative and qualitative ratio) require changes for an adequate reaction to changes in each factor of the external environment, as well as how the changes of internal variables are interconnected in the system aspect. In this model each line of the matrix resources shows which part of the resources is allocated to the structural element of the enterprise for solving the task of adaptation to each of the factors in the external environment. Thus, the greater number of aspects is involved in transformations, the more active will be the reaction of the organizational system to changes of the external environment. However, apart from the number of the elements involved, the strength of their interactions, the nature of organizational relationships are of great importance, i.e. the content and effectiveness of changes at pharmaceutical enterprises are additionally determined by the type and characteristics of its structure.

In this model, the structural interaction matrix is a table that describes quantitatively the degree of interaction (coordination) of subdivisions of the enterprise in solving problems of adaptation. The degree of interaction of subdivisions can be assessed in arbitrary units ranging from 0 - the complete lack of interaction to 1 - the maximum possible interaction. For our study the information about the degree of interaction of such structural subdivisions of the pharmaceutical enterprise "A" as Production department, Financial department, Marketing department, HR department and Sales department was of interest. The degrees of interactions of subdivisions for the given pharmaceutical enterprise determined by the assessments of the managers of subdivisions are presented in Table.

For the pharmaceutical enterprise " $A$ " the degree of interaction of financial and production structures can be called high (the degree of interaction -0.8 ). Finance and marketing functional areas interact the most densely (the degree of interaction - 0.9) and the Financial department with the Sales department (0.9). The internal interaction (self interaction) of each subdivision is maximal (1.0) (the diagonal cells of the matrix). The low interaction is observed between the Production department with the Sales department $(0.3)$ and the HR department (0.3). The degree of interaction of the Marketing and the Production department -0.3 indicates a low level of implementation of marketing management at the enterprise. However, the lowest is the interaction of the HR department with subdivisions of the enterprise, namely: financial (0.1) and marketing (0.2) services, the Sales department (0.2) and the Production department (0.3).

Depending on the type of the structure and sociopsychological, administrative, technological and other features of the enterprise the structure matrix can take an intermediate form from complete absence of interaction to the ideal interaction. For example, pharmaceutical enterprises that have a functional structure are characterized with a weak interaction of subdivisions in the process of adaptive transformations; a high degree of interaction is typical for matrix and multidimensional structures $[1,7]$. For the pharmaceutical enterprise "A" the organizational structure according to the principle of functional departmentalization is typical. A weak interaction of subdivisions leads to manifestation of discrepancies in the goals of the subdivisions with the general purposes of the enterprise. The presence of the interaction leads to excellent results - increase in the ef- 
The degrees of interaction of subdivisions at the pharmaceutical enterprise " $\mathrm{A}$ "

\begin{tabular}{|l|c|c|c|c|c|}
\hline & $\begin{array}{c}\text { Production } \\
\text { department }\end{array}$ & $\begin{array}{c}\text { Financial } \\
\text { department }\end{array}$ & $\begin{array}{c}\text { Marketing } \\
\text { department }\end{array}$ & HR department & $\begin{array}{c}\text { Sales } \\
\text { department }\end{array}$ \\
\hline Production department & 1 & 0.8 & 0.3 & 0.3 & 0.3 \\
\hline Financial department & 0.8 & 1 & 0.9 & 0.1 & 0.9 \\
\hline Marketing department & 0.3 & 0.9 & 1 & 0.2 & 0.8 \\
\hline HR department & 0.3 & 0.1 & 0.2 & 1 & 0.2 \\
\hline Sales department & 0.3 & 0.9 & 0.8 & 0.2 & 1 \\
\hline
\end{tabular}

fectiveness of the system at the expense of rational relations and the unidirectionality of actions. This result is manifested in the fact that in the presence of interaction the speed of elimination of inconsistencies by the specific environmental factor will depend on the contribution of each structural subdivision of the enterprise even if no resources are allocated to this department for solving the problem of transformation targeted to this factor.

For effective actuation of the model of adaptation of pharmaceutical enterprises to changes in the external environment on the basis of interaction of its subdivisions it is necessary to create the appropriate organizational and economic preconditions. To do this at first the organizational form for conducting the analysis of the external environment should be specified. When studying specific areas of the external environment the company may apply to specialized research organizations, such as consulting and information firms, scientific research institutes, higher schools, and conduct research on their own. For the pharmaceutical enterprise "A" the introduction of the model of adaptation of the organizational structure to changes in the external environment is imposed on employees of the Marketing department, they have significant internal resources to perform this task.

The first stage of the model is to monitor environmental factors taking into account the possible information uncertainty. When performing this kind of work it is advisable to combine efforts of the Marketing department with other departments involved in the study of certain aspects of the external environment (Fig. 2).

Therefore, it is necessary to divide powers and responsibilities between the subdivisions in the system of studying the enterprise external environment, as well as to establish information interaction in such a way that there is no duplication of works and at the same time without the information gaps in any areas. This primarily concerns the interaction of the Sales department with the Financial department and the Production department. And the Marketing department should not only collect information from the subdivisions, but also coordinate and direct their efforts to more active data collection concerning the external environment. It is necessary to develop and give recommendations to employees of the enterprise about what, where and from who the information should be collected. The activity in researching the external environment should be carried out with the active support of the top management, which must provide the Marketing department with the open access to information resources of the company, including confidential ones, as well as provide it with the information obtained from its own channels.

All the information collected, processed and analyzed should be stored in databases of customers, suppliers, competitors, contact audiences and macroenvironmental factors. Databases should be designed in a way that could provide information about the environment to different users with the necessary level of detail to them. All databases should be interrelated and must be updated as new information becomes available, particularly in the monitoring process. The final stage of the analysis of the external environment is preparation and presentation of the report to top management of the pharmaceutical enterprise and its subdivisions.

The next step is to analyze the information, and it is the responsibility of the Marketing department. The results of the analysis of deviation of the pharmaceutical enterprise state from the requirements dictated by changes in the external environment are provided by the Marketing department to the heads of the Production department, Financial department, Sales department and other subdivisions and management (CEO, commercial director, director of quality, director of production and $\mathrm{CFO}$ ). After that the management decision to implement adequate transformations in the internal environment of pharmaceutical enterprises is made by top management and the heads of the departments involved in adaptive changes of the internal environment in a constant adaptation to changes in the external environment. To adapt pharmaceutical enterprises to changes in the external environment it is necessary to allocate the appropriate resources (information, financial, etc.). In this case, all costs for adaptive transformations of pharmaceutical companies should be viewed as investments in pharmaceutical enterprises that promote timely elimination of dangers and use of opportunities, which benefits can have a long-lasting character.

For example, the pharmaceutical enterprise " $\mathrm{A}$ " solves the problem of creating a new area for drug manufacturing certified in accordance with the requirements of GMP in order to adapt to consumer new demands for quality and cost of the products. In the process of transformations the production effectively masters allocated material, financial and information resources (Sales department, Marketing department and Financial 


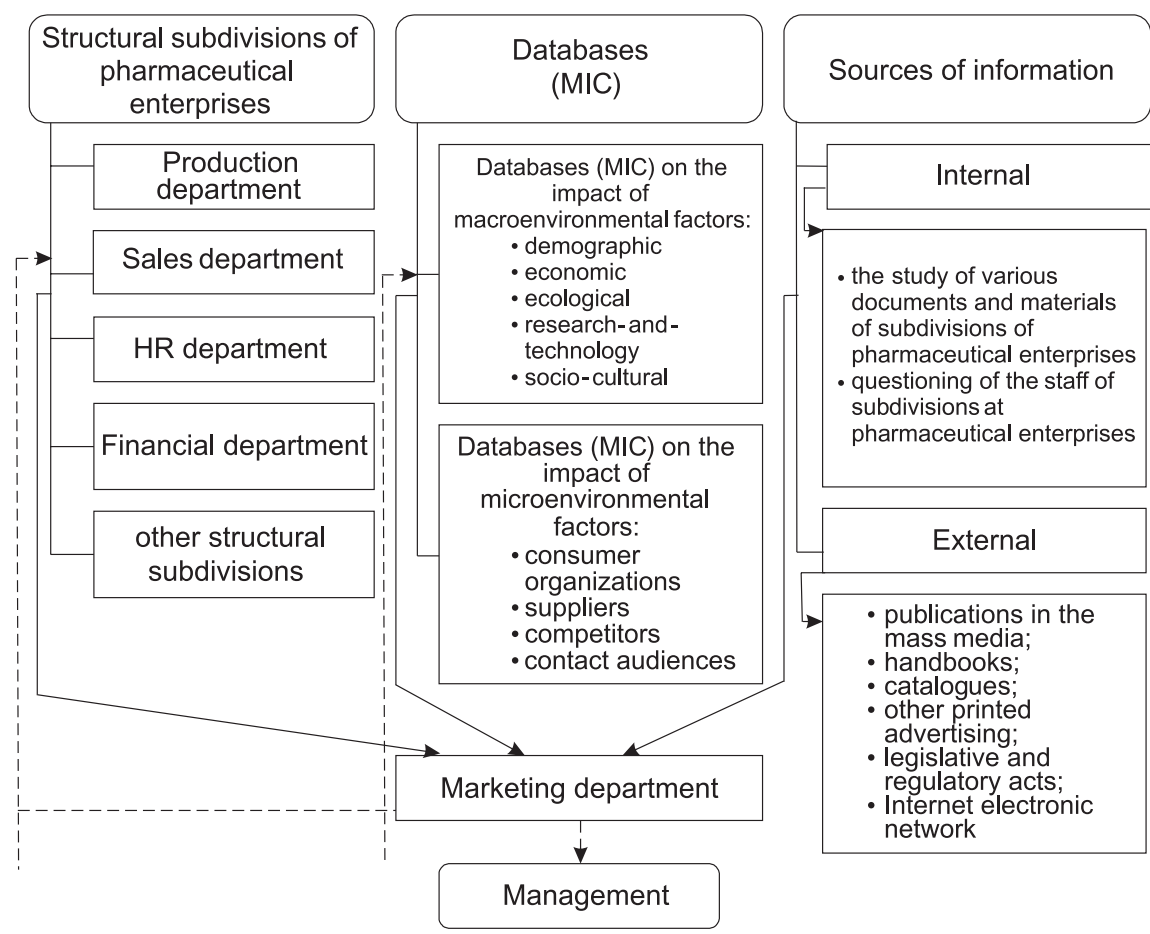

Direction of information accumulated in the Marketing department

Direction of providing the collected and processed information

Fig. 2. The scheme of collection and subsequent transfer of information concerning the external environment of the pharmaceutical enterprise " $\mathrm{A}$ " and its influence on the structural subdivisions.

department). As part of this transformation the HR department of the enterprise is tasked regarding recruitment of the staff with the skills needed for work on the new equipment. The presence of effective communications in the form of horizontal and diagonal (including informal) relationships between production and the HR department allows managers of these subdivisions to coordinate additionally the requirements to potential employees reasonably going beyond the formal job descriptions. Under these conditions the work of HR will be more focused because it would better consider the requirements of the "customer", and it improves the quality of selection and reduces the time to find candidates by the head of the Production department. Thus, the interaction between two subdivisions provides multiplication of efforts and the unidirectionality of actions increasing the response rate of the entire enterprise.

The head of the Marketing Department will be responsible for the control and operation of the model developed. The heads of departments together with employees of the Marketing department will provide the legal support for the model.
It is expedient to use this model for preserving and strengthening the competitiveness of pharmaceutical enterprises at the domestic pharmaceutical market.

\section{CONCLUSIONS}

1. The peculiarities of application of the model of adaptation of the organizational structure of pharmaceutical enterprises to changes in the external environment, which appropriately describes the process of transformation of the internal environment of the organization in a constant adaptation to environmental changes, are given.

2. The efficiency and speed of the adaptation process of pharmaceutical enterprises are determined by systemic relationship of three matrices: harmonization, which determines the principles and dynamics of interactive planning and evaluation of the results of adaptive transformations; resources determining the rationality of their distribution between the structural subdivisions of the enterprise to implement transformations; structural interaction that determines the optimal interaction based on the in-house staff motivation and other social and psychological factors.

\section{REFERENCES}

1. Бондарєва I.В. Актуальні питання створення нових лікарських засобів // Матер. Всеукр. наук.-практ. конф. студ. та молодих учених, 23-24 квітня 2009 р., м. Харків. - Х.: Вид-во НФаУ, 2009. - С. 308.

2. Бондарєва I.В. Актуальні питання створення нових лікарських засобів // Матер. Всеукр. наук.-практ. конф. студ. та молодих учених, 21-22 квітня 2010 р., м. Харків. - Х.: Вид-во НФаУ, 2010. - С. 345.

3. Михненко П.А. // Менеджмент в России и за рубежом. - 2008. - №3. - С. 3-10. 
4. Пестун І.В. Моделювання процесу адаптації фармацевтичного підприємства до змін зовнішнього середовища: Метод. рекоменд. / І.В.Пестун, І.В.Бондарєва. - Х.: Вид-во НФаУ, 2010. - 24 с.

5. Frishammar J. // Management Decision. - 2003. - Vol. 41, №4. - P. 318-326.

6. Hough J. // Management Decision. - 2004. - Vol. 42, №6. - P. 781-793.

7. Karim N. // Library Review. - 2004. - Vol. 53, №7. - P. 356-362.

8. Velitchka D. // J. of Marketing. - 2006. - Vol. 70, №1. - P. 107-118.

9. Walsh P. // Management Decision. - 2005. - Vol. 43, №1. - P. 113-122.

10. Yunggar M. // J. of American Academy of Business, Cambridge. - 2005. - Vol. 6, №2. - P. 324-331.

\section{ОСОБЛИВОСТІ ЗАСТОСУВАННЯ МОДЕЛІ АДАПТАЦІЇ ОРГАНІЗАЦІЙНОЇ СТРУКТУРИ} ФАРМАЦЕВТИЧНИХ ПІДПРИЄМСТВ ДО ЗМІН ЗОВНІШНЬОГО СЕРЕДОВИЩА І.В.Бондарєва

Ключові слова: модель адаптації; організаційна структура; структурні підрозділи; фоктори зовнішнього середовища; виробничі фрармацевтичні підприємства На теперішній час високий ступінь невизначеності та нестабільності зовнішнього середовища обумовлює зростання значущості адаптації сучасних організацій до нових реалій. Для ефективного функціонування виробничих фрармацевтичних підприємств необхідно використання методики, що дозволяє в режимі постійної адаптації до змін зовнішнього середовища описати процеси перетворень внутрішнього середовища. Надані особливості застосування моделі адаптації фрармацевтичних підприємств до змін зовнішнього середовища на засадах взаємодії його підрозділів. Ефрективність і швидкість процесу адаптації фрармацевтичних підприємств визначаються системним взаємозв'язком трьох матриць: узгодження, яка визначає принципи і динаміку інтерактивного планування і оцінювання результатів адаптаційних перетворень; ресурсів, яка визначає раціональність їх розподілу між структурними одинииями підприємства для здійснення перетворень; структурної взаємодії, що визначає оптимальну внутрішньоорганізаційну взаємодію з урахуванням мотивації співробітників та інших соціально-психологічних чинників. Проаналізовано процес адаптації для випадку, коли на зміну двох суттєвих фракторів зовнішнього середовища фрармацевтичне підприємство реагує зміною трьох його структурних підрозділів. Надано механізм збору і подальшої передачі інорормації стосовно зовнішнього середовища на виробничому фармацевтичному підприємстві та його впливу на структурні підрозділи організації. Використання даної моделі є доцільним для збереження і посилення конкурентоспроможності фармацевтичних підприємств на вітчизняному формацевтичному ринку.

\section{ОСОБЕННОСТИ ПРИМЕНЕНИЯ МОДЕЛИ АДАПТАЦИИ ОРГАНИЗАЦИОННОЙ СТРУКТУРЫ ФАРМАЦЕВТИЧЕСКИХ ПРЕДПРИЯТИЙ К ИЗМЕНЕНИЯМ ВНЕШНЕЙ СРЕДЫ И.В.Бондарева}

Ключевые слова: модель адаптации; организационная структура; структурные подразделения; фракторы внешней среды; производственные фрармацевтические предприятия

Сегодня высокая степень неопределенности и нестабильности внешней среды обусловливает рост значимости адаптации современных организаций к новым реалиям. Для эфффективного фрункционирования производственных фрармацевтических предприятий необходимо использование методики, позволяющей в режиме постоянной адаптации к изменениям внешней среды описывать процессы преобразований внутренней среды. Представлены особенности применения модели адаптации фрармацевтических предприятий к изменениям внешней среды на основе взаимодействия его подразделений. Эфффективность и скорость процесса адаптации фрармацевтических предприятий определяются системной взаимосвязью трех матриц: согласования, которая определяет принципы и динамику интерактивного планирования и оценки результатов адаптационных преобразований; ресурсов, которая определяет рациональность их распределения между структурными единицами предприятия для осуществления преобразований; структурного взаимодействия, которая определяет оптимальное внутриорганизационное взаимодействие с учетом мотивации сотрудников и других социально-психологических фракторов. Проанализирован процесс адаптации в случае, когда на смену двух существенных фракторов внешней среды фрармацевтическое предприятие реагирует изменением трех его структурных подразделений. Предоставлен механизм сбора и последующей передачи информации о внешней среде на производственном фрармацевтическом предприятии и ее влияния на его структурные подразделения. Использование данной модели целесообразно для сохранения и усиления конкурентоспособности фрармацевтических предприятий на отечественном фрармацевтическом рынке. 